\title{
Three Novel Biphenanthrene Derivatives and a New Phenylpropanoid Ester from Aerides multiflora and Their $\alpha$-Glucosidase Inhibitory Activity
}

\author{
May Thazin Thant ${ }^{1,2}$, Boonchoo Sritularak ${ }^{1,3, *}$, Nutputsorn Chatsumpun ${ }^{4}$, Wanwimon Mekboonsonglarp ${ }^{5}$, \\ Yanyong Punpreuk ${ }^{6}$ and Kittisak Likhitwitayawuid ${ }^{1}$ (i) \\ 1 Department of Pharmacognosy and Pharmaceutical Botany, Faculty of Pharmaceutical Sciences, \\ Chulalongkorn University, Bangkok 10330, Thailand; maythazinthant@mohs.edu.mm (M.T.T.); \\ Kittisak.L@chula.ac.th (K.L.) \\ 2 Department of Pharmacognosy, University of Pharmacy, Yangon 11031, Myanmar \\ 3 Natural Products for Ageing and Chronic Diseases Research Unit, Faculty of Pharmaceutical Sciences, \\ Chulalongkorn University, Bangkok 10330, Thailand \\ 4 Department of Pharmacognosy, Faculty of Pharmacy, Mahidol University, Bangkok 10400, Thailand; \\ nutputsorn.cha@mahidol.ac.th \\ 5 Scientific and Technological Research Equipment Centre, Chulalongkorn University, \\ Bangkok 10330, Thailand; wanwimon.m@chula.ac.th \\ 6 Department of Agriculture, Kasetsart University, Bangkok 10900, Thailand; cyyp01@hotmail.co.th \\ * Correspondence: boonchoo.sr@chula.ac.th; Tel.: +66-2218-8356
}

check for updates

Citation: Thant, M.T.; Sritularak, B.; Chatsumpun, N.; Mekboonsonglarp, W.; Punpreuk, Y.; Likhitwitayawuid, K. Three Novel Biphenanthrene Derivatives and a New Phenylpropanoid Ester from Aerides multiflora and Their $\alpha$-Glucosidase Inhibitory Activity. Plants 2021, 10, 385. https://doi.org/10.3390/ plants10020385

Academic Editor: Stefania Lamponi Received: 22 January 2021

Accepted: 16 February 2021

Published: 17 February 2021

Publisher's Note: MDPI stays neutral with regard to jurisdictional claims in published maps and institutional affiliations.

Copyright: (C) 2021 by the authors Licensee MDPI, Basel, Switzerland. This article is an open access article distributed under the terms and conditions of the Creative Commons Attribution (CC BY) license (https:/ / creativecommons.org/licenses/by/ $4.0 /)$.

\begin{abstract}
A phytochemical investigation on the whole plants of Aerides multiflora revealed the presence of three new biphenanthrene derivatives named aerimultins A-C (1-3) and a new natural phenylpropanoid ester dihydrosinapyl dihydroferulate (4), together with six known compounds (5-10). The structures of the new compounds were elucidated by analysis of their spectroscopic data. All of the isolates were evaluated for their $\alpha$-glucosidase inhibitory activity. Aerimultin C (3) showed the most potent activity. The other compounds, except for compound 4, also exhibited stronger activity than the positive control acarbose. Compound 3 showed non-competitive inhibition of the enzyme as determined from a Lineweaver-Burk plot. This study is the first phytochemical and biological investigation of $A$. multiflora.
\end{abstract}

Keywords: Aerides multiflora; Orchidaceae; $\alpha$-glucosidase inhibition; biphenanthrene derivatives; phenylpropanoid ester

\section{Introduction}

Diabetes mellitus (DM) is one of the main causes of global morbidity and mortality [1]. The disease is caused by insufficient insulin secretion and/or action. DM is associated with high blood glucose levels, and type $2 \mathrm{DM}$ is the most common form, covering 90-95\% of all diabetes cases [2]. Drugs currently used for treating DM can be classified into several classes following their chemical structures and modes of action, and some have limitations due to their adverse reactions or unpleasant effects [3]. $\alpha$-Glucosidase is an enzyme located in the small intestine. It is responsible for converting starch and disaccharides into monosaccharides (glucose). Inhibition of this enzyme can significantly reduce postprandial hyperglycemia [4]. $\alpha$-Glucosidase inhibitors (AGIs) have been widely used in combination with other anti-DM drugs in the management of type 2 DM [5-8].

However, AGIs can cause liver injuries and gastrointestinal side effects $[9,10]$. There has been a growing interest in developing antidiabetic drugs of botanical origin because they are perceived as possessing fewer undesired effects [11,12]. Several promising AGIs have been reported from some members of the family Orchidaceae, such as Dendrobium tortile [13], Bulbophyllum retusiusculum [14], and Arundina graminifolia [15]. 
Aerides is a small genus of epiphytes in the family Orchidaceae. It consists of approximately 21 species that are native to South and South-East Asia [16]. Some Aerides species have been used in traditional medicine. For example, Aerides falcata has been used for boosting the immune system, whereas Aerides odoratum has been known for its antibacterial properties [17]. Phytochemical screening of Aerides odoratum suggested the presence of alkaloids, glycosides, flavonoids, saponins, tannins, terpenoids, steroids, and anthroquinones [18]. Several phenanthrene derivatives have been identified from Aerides rosea [19] and Aerides crispum [20].

Aerides multiflora Roxb. (Figure 1) is commonly known as "The Multi-flowered Aerides" [21] and called "Malai Dang" in Thai [22]. It has several synonyms, including Aerides affinis, Aerides godefroyana, Aerides lobbii, Cleisostoma vacherotiana, and Epidendrum geniculatum [23]. The plant is indigenous to Bangladesh, India, Nepal, Myanmar, Thailand, Malaysia, Philippines, Laos, Cambodia, and Vietnam. A. multiflora has been traditionally used as a tonic [24]. It has also been used to treat cuts and wounds [17,25] and fractured and dislocated bones [26]. In an earlier study, its tubers showed an antibacterial effect in vitro [27]. As a continuation of our investigation of orchids for $\alpha$-glucosidase inhibitors [28-30], a MeOH extract obtained from the whole plants of Aerides multiflora was evaluated and found to possess strong inhibitory property against the enzyme $(82.4 \pm 9.5 \%$ inhibition at $100 \mu \mathrm{g} / \mathrm{mL}$ ). In this communication, we describe our findings on the chemical constituents of this plant and their $\alpha$-glucosidase inhibitory activity.
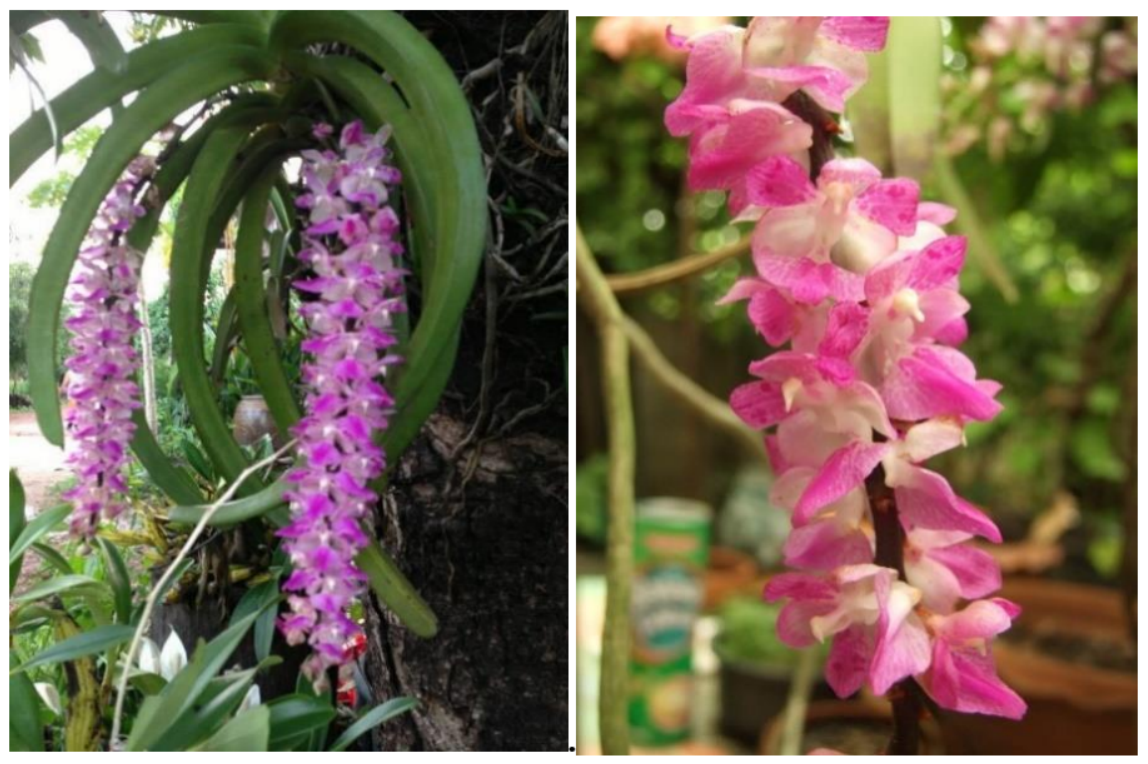

Figure 1. Aerides multiflora Roxb.

\section{Results and Discussion}

\subsection{Structural Characterization}

A total of 10 polyphenolic compounds were isolated from the $\mathrm{MeOH}$ extract of Aerides multiflora through solvent partition and repeated chromatography. They were characterized as three unknown compounds, named aerimultins A-C (1-3) and a new natural product, dihydrosinapyl dihydroferulate (4), together with six known compounds, i.e., 6-methoxycoelonin (5) [31], gigantol (6) [32], imbricatin (7) [33], agrostonin (8) [34], dihydroconiferyl dihydro-p-coumarate (9) [35] and 5-methoxy-9,10-dihydro- phenanthrene2,3,7-triol (10) [36] (Figure 2). 

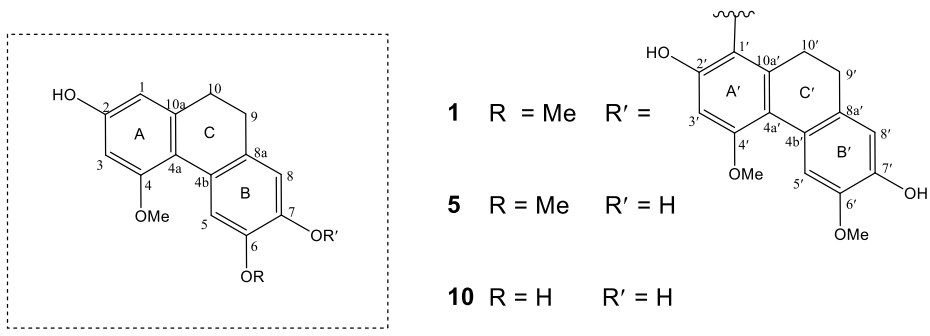

$10 \mathrm{R}=\mathrm{H} \quad \mathrm{R}^{\prime}=\mathrm{H}$

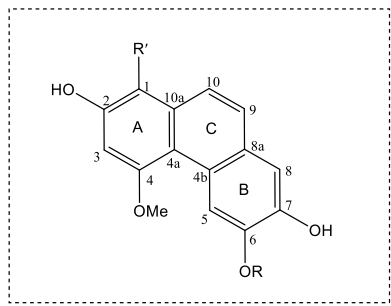

$2 \mathrm{R}=\mathrm{Me} \mathrm{R}^{\prime}=$

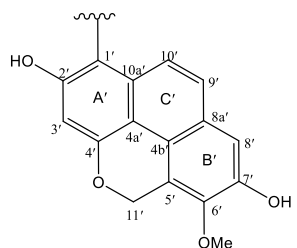

$3 \mathrm{R}=\mathrm{H} \quad \mathrm{R}^{\prime}=$

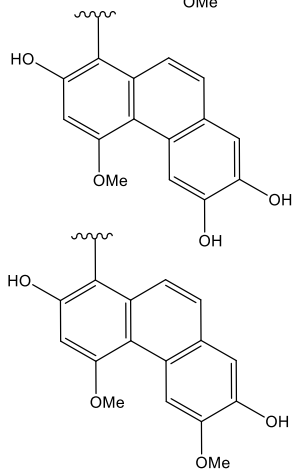<smiles></smiles>

$8 \mathrm{R}=\mathrm{Me} \quad \mathrm{R}^{\prime}=$<smiles>[2H]c1cc(CCCOC(=O)CCc2ccc(O)c(Br)c2)cc(OC)c1O</smiles>
$9 \mathrm{R}=\mathrm{H}$

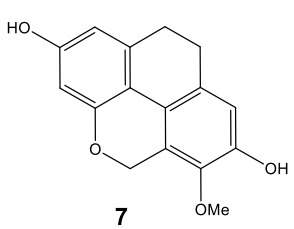

Figure 2. Chemical structures of compounds 1-10 isolated from Aerides multiflora.

Compound 1 was isolated as a whitish-brown amorphous solid. It showed a $[\mathrm{M}+\mathrm{Na}]^{+}$ at $m / z 565.1841$ (calculated for $\mathrm{C}_{32} \mathrm{H}_{30} \mathrm{O}_{8} \mathrm{Na}, 565.1838$ ) in the HR-ESI-MS. The IR spectrum showed absorption bands for hydroxyl $\left(3350 \mathrm{~cm}^{-1}\right)$, aromatic ring $\left(2923,1605 \mathrm{~cm}^{-1}\right)$, methylene $\left(1462 \mathrm{~cm}^{-1}\right)$ and ether $\left(1221 \mathrm{~cm}^{-1}\right)$ groups. The UV absorptions at 265,305 , and $315 \mathrm{~nm}$ were indicative of a dihydrophenanthrene skeleton [37]. The ${ }^{13} \mathrm{C}$ NMR and HSQC spectra revealed signals for twenty-four aromatic carbons, plus eight aliphatic carbons representing four methoxy and four methylene groups. The four $\mathrm{CH}_{2}$ carbons at 29.0 (C-9), $31.4(\mathrm{C}-10), 29.9\left(\mathrm{C}-9^{\prime}\right)$, and $24.1\left(\mathrm{C}-10^{\prime}\right)$ displayed HSQC correlations to the protons at $\delta 2.45\left(2 \mathrm{H}, \mathrm{m}, \mathrm{H}_{2}-9\right)$ and $2.56\left(2 \mathrm{H}, \mathrm{m}, \mathrm{H}_{2}-10\right)$ and $2.52\left(4 \mathrm{H}, \mathrm{br} \mathrm{s}, \mathrm{H}_{2}-9^{\prime}, \mathrm{H}_{2}-10^{\prime}\right)$, respectively. These NMR signals suggested that $\mathbf{1}$ should be a dimeric compound consisting of two units of 9,10-dihydrophenanthrene (Table 1). The first unit of $\mathbf{1}$ (rings A, B, and C) should be derived from methoxycoelonin (5), a dihydrophenanthrene also obtained in this study, because its ${ }^{1} \mathrm{H}$ and ${ }^{13} \mathrm{C}$ NMR properties bore a close resemblance to those of 5 (Table 1). For example, in ring $A$ of the first unit of $\mathbf{1}$, the proton at $C-1(\delta 6.35,1 \mathrm{H}, \mathrm{d}, J=2.5 \mathrm{~Hz})$ exhibited HMBC correlation with C-10 ( $\delta 31.4)$ and NOESY interaction with $\mathrm{H}_{2}-10 . \mathrm{H}-3(\delta 6.46,1 \mathrm{H}$, $\mathrm{d}, J=2.5 \mathrm{~Hz}$ ) of 1 showed a NOESY cross peak with MeO-4 protons $(\delta 3.89,3 \mathrm{H}, \mathrm{s})$. The hydroxyl proton at C-2 was observed at $\delta 8.35(1 \mathrm{H}, \mathrm{s})$. For ring $\mathrm{B}$ of $\mathbf{1}$, the following ${ }^{1} \mathrm{H}$ NMR signals were found: two one-proton singlets at $\delta 6.33(1 \mathrm{H}, \mathrm{s}, \mathrm{H}-8)$ and $7.98(1 \mathrm{H}, \mathrm{s}, \mathrm{H}-5)$, and a three-proton singlet at $\delta 3.92(3 \mathrm{H}, \mathrm{s}, \mathrm{MeO}-6)$ which showed a NOESY cross-peak with $\mathrm{H}-5$. The second unit of $\mathbf{1}$ (rings $\mathrm{A}^{\prime}, \mathrm{B}^{\prime}$, and $\mathrm{C}^{\prime}$ ) also exhibited ${ }^{1} \mathrm{H}$ and ${ }^{13} \mathrm{C}$ NMR data similar to those of 5 (Table 1). For instance, the ${ }^{1} \mathrm{H}$ NMR spectrum of $\mathbf{1}$ exhibited two singlet proton 
signals at $6.66\left(1 \mathrm{H}, \mathrm{s}, \mathrm{H}-8^{\prime}\right)$ and $7.93\left(1 \mathrm{H}, \mathrm{s}, \mathrm{H}-5^{\prime}\right)$, two methoxy groups at $\delta 3.84(3 \mathrm{H}, \mathrm{s}$, MeO-6 $\left.{ }^{\prime}\right)$ and $3.91\left(3 \mathrm{H}, \mathrm{s}, \mathrm{MeO}-4^{\prime}\right)$, and two hydroxyl groups at $\delta 7.44\left(\mathrm{~s}, \mathrm{HO}-7^{\prime}\right)$ and 8.25 (s, HO- $\left.2^{\prime}\right)$. The HMBC spectrum of 1 showed correlation from H-3 ${ }^{\prime}$ to C-1' $(\delta 133.7)$ and C- $4 \mathrm{a}^{\prime}$

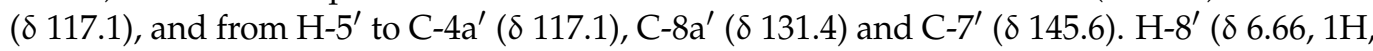
s) displayed HMBC correlation with C-9' $(\delta 29.9)$ and NOESY interaction with $\mathrm{H}_{2}-9^{\prime}$. The methoxyl protons at C- $4^{\prime}(\delta 155.3)$ and C- $6^{\prime}(\delta 146.1)$ showed NOESY correlations with H-3' and $\mathrm{H}^{-} 5^{\prime}$, respectively. However, the second dihydrophenanthrene unit of $\mathbf{1}$ showed the absence of a $\mathrm{H}-1^{\prime}$ signal, with the signal for $\mathrm{H}-3^{\prime}$ appearing as a singlet at $\delta 6.65$. Moreover, in the ${ }^{13} \mathrm{C}$ NMR spectrum of $\mathbf{1}$, the signal for $\mathrm{C}-1^{\prime}$ of this unit was downfield shifted and observed as a quaternary carbon at $\delta 133.7$, with $\mathrm{HMBC}$ correlations with $\mathrm{H}-3^{\prime}(\delta 6.65, \mathrm{~s})$, $\mathrm{H}_{2}-10^{\prime}(\delta 2.52, \mathrm{br} \mathrm{s})$ and $\mathrm{HO}-2^{\prime}(\delta 8.25, \mathrm{~s})$. These NMR properties indicated that the structure of 1 consisted of two methoxycoelonin (5) units connected to each other through an ether linkage at C-7 and C- $1^{\prime}$. This was also supported by the absence of a hydroxyl proton at C-7 ( $\delta 146.6)$. Based on the above spectral data, compound 1 was characterized as a new dimeric 9,10-dihydrophenanthrene derivative and given the trivial name aerimultin $\mathrm{A}$.

Table $1 .{ }^{1} \mathrm{H}(500 \mathrm{MHz})$ and ${ }^{13} \mathrm{C}-\mathrm{NMR}(125 \mathrm{MHz})$ spectral data of $\mathbf{1}$ and $\mathbf{5}$ in acetone- $d_{6}$.

\begin{tabular}{|c|c|c|c|c|c|}
\hline \multirow[b]{2}{*}{ Position } & \multirow{2}{*}{$\begin{array}{c}1^{\mathrm{a}} \\
\delta_{\mathrm{H}}(\text { Multiplicity, } \\
J \text { in Hz) }\end{array}$} & \multirow[b]{2}{*}{$\delta_{C}$} & \multicolumn{3}{|c|}{$5^{b}$} \\
\hline & & & $\begin{array}{c}\text { HMBC (Correlation } \\
\left.\text { with }{ }^{1} \mathbf{H}\right)\end{array}$ & $\delta_{H}($ Multiplicity, $J$ in $\mathrm{Hz})$ & $\delta_{C}$ \\
\hline 1 & $6.35(\mathrm{~d}, J=2.5 \mathrm{~Hz})$ & 108.3 & $3,10, \mathrm{HO}-2$ & 6.39 (br s) & 107.4 \\
\hline 2 & - & 157.8 & $1 *, 3 *, \mathrm{HO}-2 *$ & - & 156.5 \\
\hline 3 & $6.46(\mathrm{~d}, J=2.5 \mathrm{~Hz})$ & 99.1 & $1, \mathrm{HO}-2$ & 6.65 (br s) & 98.3 \\
\hline 4 & - & 158.8 & $3 *, \mathrm{MeO}-4$ & - & 157.7 \\
\hline $4 a$ & - & 115.9 & $1,3,5,10$ & - & 115.5 \\
\hline $4 b$ & - & 127.8 & $5 *, 8,9$ & - & 124.7 \\
\hline 5 & $7.98(\mathrm{~s})$ & 114.3 & - & 7.89 (s) & 112.2 \\
\hline 6 & - & 147.4 & 8, MeO-6 & - & 145.1 \\
\hline 7 & - & 146.6 & 5 & - & 144.3 \\
\hline 8 & $6.33(\mathrm{~s})$ & 113.6 & 9 & $6.69(\mathrm{~s})$ & 114.0 \\
\hline $8 a$ & - & 131.1 & 5,10 & - & 130.7 \\
\hline 9 & $2.45(\mathrm{~m})$ & 29.0 & 8 & $2.61(\mathrm{~m})$ & 28.9 \\
\hline 10 & $2.56(\mathrm{~m})$ & 31.4 & 1 & $2.61(\mathrm{~m})$ & 30.7 \\
\hline $10 \mathrm{a}$ & - & 141.6 & $9,10 *$ & - & 140.5 \\
\hline $1^{\prime}$ & - & 133.7 & $3^{\prime}, 10^{\prime}, \mathrm{HO}-2^{\prime}$ & & \\
\hline $2^{\prime}$ & - & 149.8 & $3^{\prime} *, \mathrm{HO}-2^{\prime} *$ & & \\
\hline $3^{\prime}$ & $6.65(\mathrm{~s})$ & 100.2 & $\mathrm{HO}-2^{\prime}$ & & \\
\hline $4^{\prime}$ & - & 155.3 & $3^{\prime} *, \mathrm{MeO}-4^{\prime}$ & & \\
\hline $4 a^{\prime}$ & - & 117.1 & $3^{\prime}, 5^{\prime}, 10^{\prime}$ & & \\
\hline $4 b^{\prime}$ & - & 125.2 & $5^{\prime} *, 8^{\prime}, 9^{\prime}$ & & \\
\hline $5^{\prime}$ & $7.93(\mathrm{~s})$ & 113.4 & - & & \\
\hline $6^{\prime}$ & - & 146.1 & $8^{\prime}, \mathrm{MeO}-6^{\prime}, \mathrm{HO}-7^{\prime}$ & & \\
\hline $7^{\prime}$ & - & 145.6 & $5^{\prime}, \mathrm{HO}-7^{\prime} *$ & & \\
\hline $8^{\prime}$ & $6.66(\mathrm{~s})$ & 114.9 & $9^{\prime}, \mathrm{HO}-7^{\prime}$ & & \\
\hline $8 a^{\prime}$ & - & 131.4 & $5^{\prime}, 10^{\prime}$ & & \\
\hline $9^{\prime}$ & 2.52 (br s) & 29.9 & $8^{\prime}$ & & \\
\hline $10^{\prime}$ & 2.52 (br s) & 24.1 & - & & \\
\hline $10 a^{\prime}$ & - & 133.8 & $9^{\prime}$ & & \\
\hline $\mathrm{MeO}-4$ & $3.89(\mathrm{~s})$ & 56.1 & - & $3.86(\mathrm{~s})$ & 55.5 \\
\hline MeO-6 & $3.92(\mathrm{~s})$ & 56.5 & - & $3.83(\mathrm{~s})$ & 54.9 \\
\hline $\mathrm{MeO}-4^{\prime}$ & $3.91(\mathrm{~s})$ & 56.4 & - & & \\
\hline $\mathrm{MeO}-6^{\prime}$ & $3.84(\mathrm{~s})$ & 55.8 & - & & \\
\hline HO-2 & $8.35(\mathrm{~s})$ & - & - & & \\
\hline HO-2' & 8.25 (s) & - & - & & \\
\hline HO-7' & $7.44(\mathrm{~s})$ & - & - & & \\
\hline
\end{tabular}

${ }^{\mathrm{a} 1} \mathrm{H}(500 \mathrm{MHz})$ and ${ }^{13} \mathrm{C}-\mathrm{NMR}(125 \mathrm{MHz}) ;{ }^{\mathrm{b} 1} \mathrm{H}(300 \mathrm{MHz})$ and ${ }^{13} \mathrm{C}-\mathrm{NMR}(75 \mathrm{MHz}) ;{ }^{*}$ two-bond coupling. 


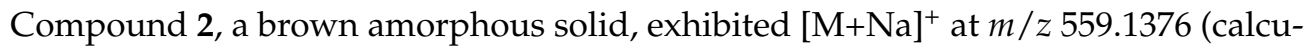
lated for $\mathrm{C}_{32} \mathrm{H}_{24} \mathrm{O}_{8} \mathrm{Na}$, 559.1368) in the HR-ESI-MS, corresponding to the molecular formula $\mathrm{C}_{32} \mathrm{H}_{24} \mathrm{O}_{8}$. The IR spectrum showed absorption bands due to the presence of hydroxyl $\left(3368 \mathrm{~cm}^{-1}\right)$, aromatic ring $\left(2919,1587 \mathrm{~cm}^{-1}\right)$ and ether $\left(1259 \mathrm{~cm}^{-1}\right)$ functionalities. The UV absorptions at 265, 315.5 and $370 \mathrm{~nm}$ were suggestive of a phenanthrene skeleton [30]. Compound 2 should be a dimeric phenanthrene, as suggested from the ${ }^{1} \mathrm{H}$ NMR signals for two pairs of ortho-coupled doublets, representing $\mathrm{H}-9(\delta 7.36,1 \mathrm{H}, \mathrm{d}, J=9.5 \mathrm{~Hz}), \mathrm{H}-10$ $(\delta 6.98,1 \mathrm{H}, \mathrm{d}, J=9.5 \mathrm{~Hz}), \mathrm{H}-9^{\prime}(\delta 7.37,1 \mathrm{H}, \mathrm{d}, J=9.0 \mathrm{~Hz})$, and $\mathrm{H}-10^{\prime}(\delta 6.92,1 \mathrm{H}, \mathrm{d}, J=9.0 \mathrm{~Hz})$ (Table 2). The first phenanthrene unit of 2 (rings $\mathrm{A}, \mathrm{B}$, and $\mathrm{C}$ ) exhibited ${ }^{1} \mathrm{H}$ and ${ }^{13} \mathrm{C}$ NMR resonances similar to those of agrostonin (8), a biphenantherene also isolated from this plant (Table 2). These included three one-proton singlets at $\delta 6.99(1 \mathrm{H}, \mathrm{s}, \mathrm{H}-3), 7.19(1 \mathrm{H}, \mathrm{s}$, $\mathrm{H}-8)$ and $9.24(1 \mathrm{H}, \mathrm{s}, \mathrm{H}-5)$, and two methoxy groups at $\delta 4.06(3 \mathrm{H}, \mathrm{s}, \mathrm{MeO}-6)$ and $4.22(3 \mathrm{H}$, $\mathrm{s}, \mathrm{MeO}-4)$. The proton at C-8 showed HMBC correlation with C-9 ( $\delta 126.5)$. The protons H-3 and H-5 exhibited three-bond couplings to C-4a $(\delta 116.2)$ in the HMBC spectrum. The NOESY correlations of the MeO- 4 and MeO- 6 protons with $\mathrm{H}-3$ and $\mathrm{H}-5$, respectively, supported the attachment of these methoxy groups at C-4 and C-6. The quaternary carbon at $\delta 109.3$ was assigned as C-1 according to its HMBC cross-peaks with H-3 and H-10. For the second phenanthrene unit (rings $\mathrm{A}^{\prime}, \mathrm{B}^{\prime}$, and $\mathrm{C}^{\prime}$ ), the presence of oxymethylene protons at $\delta 5.79\left(2 \mathrm{H}, \mathrm{d}, J=1.5 \mathrm{~Hz}, \mathrm{H}_{2}-11^{\prime}\right)$ indicated a phenanthropyran structure [38]. The ${ }^{1} \mathrm{H}$ NMR spectrum also displayed two sharp one-proton singlets at $\delta 6.81\left(1 \mathrm{H}, \mathrm{s}, \mathrm{H}-3^{\prime}\right)$ and $7.21\left(1 \mathrm{H}, \mathrm{s}, \mathrm{H}-8^{\prime}\right)$, and a methoxy group at $\delta 3.95\left(3 \mathrm{H}, \mathrm{s}, \mathrm{MeO}-6^{\prime}\right)$. The assignments of $\mathrm{H}-8^{\prime}$ and $\mathrm{H}-3^{\prime}$ were supported by their HMBC correlations with C-9' $(\delta 127.9)$ and $C-1^{\prime}(\delta 110.2)$, respectively. The HMBC correlations of C-6 ${ }^{\prime}\left(\delta\right.$ 144.2) with $\mathrm{MeO}-6^{\prime}$ protons and $\mathrm{H}_{2}-11^{\prime}$ indicated the location of the methoxy group at $\mathrm{C}-6^{\prime}$. The $\mathrm{C}-1^{\prime}$ of this second unit showed HMBC correlations with H-3' and H-10'. The chemical shifts of C-1 ( $\delta 109.3)$ and C- ${ }^{\prime}$ ( $\delta$ 110.2) suggested that they were not oxygenated, but, instead, they formed a $C-C$ bridge linking the two monomers [39]. Therefore, it was concluded that $\mathbf{2}$ had the structure as shown, and the compound was given the trivial name aerimultin $\mathrm{B}$.

Compound 3 was obtained as a brown amorphous solid. Its UV absorptions and IR absorption bands were similar to those of compound 2, indicating a phenanthrene derivative. The HR-ESI-MS exhibited [M+Na] ${ }^{+}$at $m / z 533.1218$ (calculated for $\mathrm{C}_{30} \mathrm{H}_{22} \mathrm{O}_{8} \mathrm{Na}$, 533.1212), suggesting the molecular formula $\mathrm{C}_{30} \mathrm{H}_{22} \mathrm{O}_{8}$. However, the ${ }^{13} \mathrm{C}$ NMR spectrum showed only 15 carbon signals, suggesting that 3 should be a dimeric phenanthrene with two identical units. Comparison of the ${ }^{1} \mathrm{H}$ and ${ }^{13} \mathrm{C}$ NMR of 3 with those of agrostonin (8) (Table 2) revealed their structural similarity, except for the presence of a hydroxyl group at C-6/C-6' in 3, instead of a methoxy group. Moreover, the two phenanthrene units were symmetrically linked to each other through a $\mathrm{C}-\mathrm{C}$ bond between $\mathrm{C}-1$ and $\mathrm{C}-\mathrm{1}^{\prime}$ as supported by the HMBC correlations from $\mathrm{C}-1 / \mathrm{C}-\mathrm{1}^{\prime}$ to $\mathrm{H}-3 / \mathrm{H}-3^{\prime}, \mathrm{H}-10 / \mathrm{H}-10^{\prime}$ and $\mathrm{HO}-2 / \mathrm{HO}-2^{\prime}$ [39]. On the basis of above spectral evidence, the structure of compound 3 was established as shown, and the trivial name aerimultin $C$ was given to the compound.

Compound 4 was obtained as a yellow amorphous solid. The molecular formula was determined as $\mathrm{C}_{21} \mathrm{H}_{26} \mathrm{O}_{7}$ by HR-ESI-MS of $[\mathrm{M}+\mathrm{Na}]^{+}$at $m / z 413.1584$ (calculated for $\mathrm{C}_{21} \mathrm{H}_{26} \mathrm{O}_{7} \mathrm{Na}$, 413.1576). The IR spectrum showed absorption bands for hydroxyl $\left(3432 \mathrm{~cm}^{-1}\right)$, aromatic ring $\left(2937,1608 \mathrm{~cm}^{-1}\right)$, carbonyl ester $\left(1723,1208,1111 \mathrm{~cm}^{-1}\right)$ and methylene $\left(1455 \mathrm{~cm}^{-1}\right)$ groups. The UV spectrum exhibited maximum absorptions at 280 and $315 \mathrm{~nm}$. The ${ }^{1} \mathrm{H}$ NMR spectrum (Table 3$)$ exhibited signals for a dihydroferulate structure [ $\delta 2.59\left(2 \mathrm{H}, \mathrm{t}, J=7.5 \mathrm{~Hz}, \mathrm{H}_{2}-8\right), 2.81\left(2 \mathrm{H}, \mathrm{m}, \mathrm{H}_{2}-7\right), 3.82(3 \mathrm{H}, \mathrm{s}, \mathrm{MeO}-3), 6.68(1 \mathrm{H}$, $\mathrm{dd}, J=8.1,1.5 \mathrm{~Hz}, \mathrm{H}-6), 6.73(1 \mathrm{H}, \mathrm{d}, J=8.1 \mathrm{~Hz}, \mathrm{H}-5)$, and $6.85(1 \mathrm{H}, \mathrm{d}, J=1.5 \mathrm{~Hz}, \mathrm{H}-2)]$ [40]. This was confirmed by the HMBC correlations of C-2 ( $\delta 111.8)$, C-6 $(\delta 120.6)$ and C-9 ( $\delta$ 172.2) with $\mathrm{H}_{2}-7$ (Table 3). The location of a MeO-3 group was supported by its NOESY correlation with $\mathrm{H}-2$. The ${ }^{1} \mathrm{H}$ NMR spectrum also showed signals for a dihydrosinapyl structure [ $\delta 1.89\left(2 \mathrm{H}, \mathrm{m}, \mathrm{H}_{2}-8^{\prime}\right), 2.57\left(2 \mathrm{H}, \mathrm{t}, J=7.5 \mathrm{~Hz}, \mathrm{H}_{2}-7^{\prime}\right), 3.80\left(6 \mathrm{H}, \mathrm{s}, \mathrm{MeO}-3^{\prime}, \mathrm{MeO}^{\prime} 5^{\prime}\right)$, $4.05\left(2 \mathrm{H}, \mathrm{t}, J=7.5 \mathrm{~Hz}, \mathrm{H}_{2}-9^{\prime}\right)$, and $6.49\left(2 \mathrm{H}, \mathrm{s}, \mathrm{H}-2^{\prime}, \mathrm{H}-6^{\prime}\right)$ ] [41]. The HMBC correlations of C-2 $2^{\prime} / C-6^{\prime}(\delta 105.8)$ and $C-9^{\prime}(\delta 63.2)$ with $\mathrm{H}_{2}-7^{\prime}$ supported the presence of this unit. 
Table 2. ${ }^{1} \mathrm{H}$ and ${ }^{13} \mathrm{C}-\mathrm{NMR}$ spectral data of 2,3 and 8 in acetone- $d_{6}$.

\begin{tabular}{|c|c|c|c|c|c|c|c|c|}
\hline \multirow[b]{2}{*}{ Position } & \multicolumn{3}{|c|}{$2^{a}$} & \multicolumn{3}{|c|}{$3^{b}$} & \multicolumn{2}{|l|}{$8^{b}$} \\
\hline & $\begin{array}{c}\delta_{\mathrm{H}} \\
\text { (Multiplicity, } \\
J \text { in Hz) }\end{array}$ & $\delta_{C}$ & $\begin{array}{c}\text { HMBC } \\
\text { (Correlation } \\
\text { with }{ }^{1} \mathbf{H} \text { ) }\end{array}$ & $\begin{array}{c}\delta_{\mathrm{H}} \\
\text { (Multiplicity, } \\
J \text { in } \mathrm{Hz} \text { ) }\end{array}$ & $\delta_{C}$ & $\begin{array}{c}\text { HMBC } \\
\text { (Correlation } \\
\left.\text { with }{ }^{1} \mathbf{H}\right)\end{array}$ & $\begin{array}{c}\delta_{\mathrm{H}} \\
\text { (Multiplicity, } \\
J \text { in Hz) }\end{array}$ & $\delta_{C}$ \\
\hline 1 & - & 109.3 & 3,10 & - & 108.8 & $3,10, \mathrm{HO}-2$ & - & 108.9 \\
\hline 2 & - & 155.0 & $3 *$ & - & 154.1 & $3 *, \mathrm{HO}-2 *$ & - & 154.2 \\
\hline 3 & $6.99(\mathrm{~s})$ & 100.0 & - & $6.95(\mathrm{~s})$ & 98.8 & HO-2 & $7.00(\mathrm{~s})$ & 99.2 \\
\hline 4 & - & 160.2 & $3 *, \mathrm{MeO}-4$ & - & 159.4 & $3 *, \mathrm{MeO}-4$ & - & 159.3 \\
\hline $4 a$ & - & 116.2 & $3,5,10$ & - & 115.1 & $3,5,10$ & - & 115.5 \\
\hline $4 b$ & - & 125.8 & 8,9 & - & 125.3 & 8,9 & - & 124.9 \\
\hline 5 & $9.24(\mathrm{~s})$ & 109.8 & - & $9.19(\mathrm{~s})$ & 112.7 & - & $9.26(\mathrm{~s})$ & 111.3 \\
\hline 6 & - & 148.5 & $\begin{array}{c}5 *, 8 \\
\mathrm{MeO}-6\end{array}$ & - & 145.3 & 8 & - & 147.6 \\
\hline 7 & - & 146.0 & $5,8^{*}$ & - & 144.1 & 5 & - & 145.2 \\
\hline 8 & 7.19 (s) & 112.2 & 9 & $7.19(\mathrm{~s})$ & 111.5 & 9 & $7.20(\mathrm{~s})$ & 112.3 \\
\hline $8 a$ & - & 128.0 & 5,10 & - & 126.7 & 5,10 & - & 127.2 \\
\hline 9 & $\begin{array}{c}7.36 \\
(\mathrm{~d}, J=9.5 \mathrm{~Hz})\end{array}$ & 126.5 & 8 & $\begin{array}{c}7.31 \\
(\mathrm{~d}, J=9.0 \mathrm{~Hz})\end{array}$ & 127.2 & 8 & $\begin{array}{c}7.37 \\
(\mathrm{~d}, J=9.0 \mathrm{~Hz})\end{array}$ & 127.1 \\
\hline 10 & $\begin{array}{c}6.98 \\
(\mathrm{~d}, J=9.5 \mathrm{~Hz})\end{array}$ & 123.3 & - & $\begin{array}{c}6.87 \\
(\mathrm{~d}, J=9.0 \mathrm{~Hz})\end{array}$ & 121.8 & - & $\begin{array}{c}6.95 \\
(\mathrm{~d}, J=9.0 \mathrm{~Hz})\end{array}$ & 122.5 \\
\hline $10 \mathrm{a}$ & - & 135.4 & 9 & - & 134.6 & 9 & - & 134.6 \\
\hline $1^{\prime}$ & - & 110.2 & $3^{\prime}, 10^{\prime}$ & - & 108.8 & $3^{\prime}, 10^{\prime}, \mathrm{HO}-2^{\prime}$ & - & 108.9 \\
\hline $2^{\prime}$ & - & 156.3 & $3^{\prime *}$ & - & 154.1 & $3^{\prime} *, \mathrm{HO}-2^{\prime} *$ & - & 154.2 \\
\hline $3^{\prime}$ & $6.81(\mathrm{~s})$ & 103.1 & - & $6.95(\mathrm{~s})$ & 98.8 & HO-2' & $7.00(\mathrm{~s})$ & 99.2 \\
\hline $4^{\prime}$ & - & 153.7 & $3^{\prime *}, 11^{\prime}$ & - & 159.4 & $3^{\prime *}, \mathrm{MeO}-4^{\prime}$ & - & 159.3 \\
\hline $4 a^{\prime}$ & - & 113.0 & $3^{\prime}, 10^{\prime}$ & - & 115.1 & $3^{\prime}, 5^{\prime}, 10^{\prime}$ & - & 115.5 \\
\hline $4 b^{\prime}$ & - & 119.1 & $8^{\prime}, 9^{\prime}, 11^{\prime}$ & - & 125.3 & $8^{\prime}, 9^{\prime}$ & - & 124.9 \\
\hline $5^{\prime}$ & - & 120.6 & $11^{\prime *}$ & $9.19(\mathrm{~s})$ & 112.7 & - & $9.26(\mathrm{~s})$ & 111.3 \\
\hline $6^{\prime}$ & - & 144.2 & $\begin{array}{l}8^{\prime}, 11^{\prime}, \\
\mathrm{MeO}-6^{\prime}\end{array}$ & - & 145.3 & $8^{\prime}$ & - & 147.6 \\
\hline $7^{\prime}$ & - & 150.3 & $8^{\prime *}$ & - & 144.1 & $5^{\prime}$ & - & 145.2 \\
\hline $8^{\prime}$ & $7.21(\mathrm{~s})$ & 111.6 & $9^{\prime}$ & $7.19(\mathrm{~s})$ & 111.5 & $9^{\prime}$ & $7.20(\mathrm{~s})$ & 112.3 \\
\hline $8 a^{\prime}$ & - & 126.2 & $10^{\prime}$ & - & 126.7 & $5^{\prime}, 10^{\prime}$ & - & 127.2 \\
\hline $9^{\prime}$ & $\begin{array}{c}7.37 \\
(\mathrm{~d}, J=9.0 \mathrm{~Hz})\end{array}$ & 127.9 & $8^{\prime}$ & $\begin{array}{c}7.31 \\
(\mathrm{~d}, J=9.0 \mathrm{~Hz})\end{array}$ & 127.2 & $8^{\prime}$ & $\begin{array}{c}7.37 \\
(\mathrm{~d}, J=9.0 \mathrm{~Hz})\end{array}$ & 127.1 \\
\hline $10^{\prime}$ & $\begin{array}{c}6.92 \\
(\mathrm{~d}, J=9.0 \mathrm{~Hz})\end{array}$ & 124.6 & - & $\begin{array}{c}6.87 \\
(\mathrm{~d}, J=9.0 \mathrm{~Hz})\end{array}$ & 121.8 & - & $\begin{array}{c}6.95 \\
(\mathrm{~d}, J=9.0 \mathrm{~Hz})\end{array}$ & 122.5 \\
\hline $10 \mathrm{a}^{\prime}$ & - & 132.2 & $9^{\prime}$ & - & 134.6 & $9^{\prime}$ & - & 134.6 \\
\hline $11^{\prime}$ & $\begin{array}{c}5.79 \\
(\mathrm{~d}, J=1.5 \mathrm{~Hz})\end{array}$ & 64.8 & - & - & - & - & - & - \\
\hline $\mathrm{MeO}-4$ & $4.22(\mathrm{~s})$ & 56.1 & - & $4.18(\mathrm{~s})$ & 55.0 & & $4.24(\mathrm{~s})$ & 55.3 \\
\hline MeO-6 & $4.06(\mathrm{~s})$ & 56.0 & - & - & - & & $4.08(\mathrm{~s})$ & 55.2 \\
\hline $\mathrm{MeO}-4^{\prime}$ & - & - & - & $4.18(\mathrm{~s})$ & 55.0 & & $4.24(\mathrm{~s})$ & 55.3 \\
\hline $\mathrm{MeO}-6^{\prime}$ & $3.95(\mathrm{~s})$ & 61.3 & - & - & - & & $4.08(\mathrm{~s})$ & 55.2 \\
\hline $\mathrm{HO}-2$ & - & - & - & $7.54(\mathrm{~s})$ & - & & $7.61(\mathrm{~s})$ & - \\
\hline $\mathrm{HO}-2^{\prime}$ & - & - & - & $7.54(\mathrm{~s})$ & - & & $7.61(\mathrm{~s})$ & - \\
\hline
\end{tabular}

${ }^{\mathrm{a} 1} \mathrm{H}(500 \mathrm{MHz})$ and ${ }^{13} \mathrm{C}-\mathrm{NMR}(125 \mathrm{MHz}) ;{ }^{\text {b }} \mathrm{H}(300 \mathrm{MHz})$ and ${ }^{13} \mathrm{C}-\mathrm{NMR}(75 \mathrm{MHz}) ;{ }^{*}$ two-bond coupling.

The NOESY cross-peak between MeO- $3^{\prime} / \mathrm{MeO}-5^{\prime}$ protons and $\mathrm{H}-2^{\prime} / \mathrm{H}-6^{\prime}$ confirmed the locations of the methoxy groups at $C-3^{\prime} / C-5^{\prime}(\delta 147.7)$. The two phenylpropanoid units were connected by an ester bond at C-9 and C-9' , as determined by HMBC correlation of C-9 ( $\delta$ 172.2) with $\mathrm{H}_{2}-9^{\prime}$. Based on the above spectroscopic evidence, compound 4 was determined as dihydrosinapyl dihydroferulate. Prior to this study, the natural occurrence of 4 was unknown. However, the compound was earlier synthesized by acylation of the lignins from Arabidopsis thaliana [42]. 
Table 3. ${ }^{1} \mathrm{H}(300 \mathrm{MHz})$ and ${ }^{13} \mathrm{C}-\mathrm{NMR}(75 \mathrm{MHz})$ spectral data of 4 in acetone- $d_{6}$.

\begin{tabular}{cccc}
\hline Position & $\begin{array}{c}\delta_{\mathbf{H}}(\mathbf{M u l t i p l i c i t y}, \\
\boldsymbol{J} \text { in Hz) }\end{array}$ & $\delta_{\mathbf{C}}$ & HMBC (Correlation with $\left.{ }^{\mathbf{1}} \mathbf{H}\right)$ \\
\hline 1 & - & 132.1 & $5,7^{*}, 8$ \\
2 & $6.85(\mathrm{~d}, J=1.5 \mathrm{~Hz})$ & 111.8 & 6,7 \\
3 & - & 147.3 & $5, \mathrm{MeO}-3, \mathrm{HO}-4$ \\
4 & - & 144.9 & $2,6, \mathrm{HO}-4^{*}$ \\
5 & $6.73(\mathrm{~d}, J=8.1 \mathrm{~Hz})$ & 114.8 & $\mathrm{HO}-4$ \\
6 & $6.68(\mathrm{dd}, J=8.1,1.5 \mathrm{~Hz})$ & 120.6 & 2,7 \\
7 & $2.81(\mathrm{~m})$ & 30.4 & $2,6,8^{*}$ \\
8 & $2.59(\mathrm{t}, J=7.5 \mathrm{~Hz})$ & 35.8 & $7^{*}$ \\
9 & - & 172.2 & $7,8^{*}, 9^{\prime}$ \\
$1^{\prime}$ & - & 131.7 & $8^{\prime}$ \\
$2^{\prime}$ & $6.49(\mathrm{~s})$ & 105.8 & $6^{\prime}, 7^{\prime}$ \\
$3^{\prime}$ & - & 147.7 & $2^{\prime *}, \mathrm{HO}-4^{\prime}, \mathrm{MeO}-3^{\prime}$ \\
$4^{\prime}$ & - & 134.2 & $2^{\prime}, 6^{\prime}, \mathrm{HO}-4^{\prime}$ \\
$5^{\prime}$ & - & 147.7 & $6^{*}, \mathrm{HO}-4^{\prime}, \mathrm{MeO}-5^{\prime}$ \\
$6^{\prime}$ & $6.49(\mathrm{~s})$ & 105.8 & $2^{\prime}, 7^{\prime}$ \\
$7^{\prime}$ & $2.57(\mathrm{t}, J=7.5 \mathrm{~Hz})$ & 31.8 & $2^{\prime}, 6^{\prime}, 8^{\prime *}, 9^{\prime}$ \\
$8^{\prime}$ & $1.89(\mathrm{~m})$ & 30.4 & $7^{\prime}, 9^{\prime *}$ \\
$9^{\prime}$ & $4.05(\mathrm{t}, J=7.5 \mathrm{~Hz})$ & 63.2 & $7^{\prime}, 8^{\prime}$ \\
$\mathrm{MeO}-3$ & $3.82(\mathrm{~s})$ & 55.3 & - \\
$\mathrm{MeO}-3^{\prime}$ & $3.80(\mathrm{~s})$ & 55.7 & - \\
$\mathrm{MeO}-5^{\prime}$ & $3.80(\mathrm{~s})$ & 55.7 & - \\
$\mathrm{HO}-4$ & $7.35(\mathrm{~s})$ & - & - \\
$\mathrm{HO}-4^{\prime}$ & $6.94(\mathrm{~s})$ & - & - \\
\hline
\end{tabular}

* Two-bond coupling.

\subsection{Chemotaxonomic Significance}

The presence of phenanthrene derivatives in Aerides multiflora is in line with the earlier findings in $A$. crispum and $A$. rosea $[19,20]$. In addition, the chemical profiles of these plants agreed with the conclusion from a molecular phylogenetic analysis that indicated their close relationships [43]. The family Orchidaceae is divided into 5 subfamilies, i.e., Epidendroideae, Orchidoideae, Vanilloideae, Cypripedioideae, and Apostasioideae [44]. So far, dimeric phenanthrenes have been reported from only two subfamilies, i.e., Epidendroideae (the genera Stanhopea, Bletilla, Pholidota, Pleione, Otochilus, Arundina, Bulbophyllum, Dendrobium, Monomeria, Cremastra, Agrostophyllum, Liparis, Cyrtopodium, Eria, Eulophia, Cirrhopetalum, Calanthe, Lusia, and Prosthechea) and Orchidoideae (the genera Spiranthes and Gymnadenia) [34,39,45-63]. No biphenanthrenes have been found outside these two subfamilies. Interestingly, a previous study revealed a monophyletic relationship between Epidendroideae and Orchidoideae [64]. Thus, from the currently available chemical data, the occurrence of biphenanthrenes could be taken as their chemotaxonomic marker. Nevertheless, additional chemical studies on the other three subfamilies are still needed to verify this postulation.

It should also be noted that the genus Aerides belongs to the same clade as Rhynchostylis [43]. Both genera have been called "the foxtail orchid" due to the erect or pendent inflorescences of closely packed flowers, and this has sometimes led to confusion. Up to the present, no reports on the secondary metabolites of the latter genus have appeared. Comparative chemical studies, in combination with detailed genetic analysis, may help shed light on the distinction between these two sister genera.

\section{3. $\alpha$-Glucosidase Inhibitory Activity}

Yeast $\alpha$-glucosidase enzyme was used in this study. In general, $\alpha$-glucosidase enzymes can be obtained from several sources, for example, Saccharomyces cerevisiae, Rattus norvegicus, and GANC-human [65]. The enzyme derived from the yeast shows approximately 55\% sequence homology with that obtained from mammalian sources [66], and therefore is 
widely employed in the investigations of natural compounds for $\alpha$-glucosidase inhibitory potential $[67,68]$.

All the isolated compounds (1-10) were initially tested for their $\alpha$-glucosidase inhibitory activity at a concentration of $100 \mu \mathrm{g} / \mathrm{mL}$. $\mathrm{IC}_{50}$ values were determined for compounds with more than $70 \%$ inhibition of the enzyme. As shown in Table 4, all compounds, except for dihydrosinapyl dihydroferulate (4), exhibited stronger activity $\left(\mathrm{IC}_{50}\right.$ $5.2-266.7 \mu \mathrm{M})$ than the drug acarbose $\left(\mathrm{IC}_{50}\right.$ value of $\left.514.4 \pm 9.2 \mu \mathrm{M}\right)$. It should be mentioned that biphenanthrenes with $\alpha$-glucosidase inhibitory activity were isolated from the family Orchidaceae for the first time in this study.

Table 4. $\alpha$-Glucosidase inhibitory activity of compounds 1-10.

\begin{tabular}{ccc}
\hline Compounds & IC $_{\mathbf{5 0}}(\boldsymbol{\mu g} / \mathbf{m L})$ & IC $_{\mathbf{5 0}}(\boldsymbol{\mu M})$ \\
\hline Aerimultin A (1) & $16.8 \pm 1.0$ & $30.9 \pm 1.9$ \\
Aerimultin B (2) & $41.8 \pm 1.3$ & $77 \pm 2.5$ \\
Aerimultin C (3) & $2.7 \pm 0.4$ & $5.2 \pm 0.7$ \\
Dihydrosinapyl dihydroferulate (4) & $\mathrm{NA}$ & $\mathrm{NA}$ \\
6-Methoxy coelonin (5) & $61.2 \pm 2.2$ & $224.8 \pm 7.8$ \\
Gigantol (6) & $52.5 \pm 1.9$ & $191.3 \pm 6.8$ \\
Imbricatin (7) & $44.9 \pm 2.1$ & $165.9 \pm 7.7$ \\
Agrostonin (8) & $20.1 \pm 2.5$ & $37.2 \pm 4.5$ \\
Dihydroconiferyl dihydro- -coumarate (9) & $88.1 \pm 2.9$ & $266.7 \pm 8.6$ \\
5-Methoxy-9,10-dihydrophenanthrene-2,3,7-triol (10) & $29.7 \pm 2.3$ & $115.2 \pm 9.1$ \\
Acarbose & $332.1 \pm 5.9$ & $514.4 \pm 9.2$ \\
\hline
\end{tabular}

NA = no inhibitory activity.

Overall, the dimeric phenanthrenes $(\mathbf{1}, \mathbf{2}, 3$, and 8) demonstrated higher activity than the monomers $(5,7$, and 10$)$, as indicated by their $\mathrm{IC}_{50}$ values (Table 4). Aerimultin C (3) was the most potent $\alpha$-glucosidase inhibitor, with an $\mathrm{IC}_{50}$ value of $5.2 \pm 0.7 \mu \mathrm{M}$. Replacing the phenolic groups at C- 6 and C- $6^{\prime}$ of this compound with methoxy groups reduced the activity by about seven-fold, as can be seen from the increased $\mathrm{IC}_{50}$ value $(37.2 \pm 4.5 \mu \mathrm{M})$ for agrostonin (8). The importance of free $\mathrm{OH}$ groups is also supported by the potent activity $\left(\mathrm{IC}_{50} 2.08 \pm 0.19 \mu \mathrm{M}\right.$ ) earlier observed for a biphenanthrene (from Dioscorea bulbifera, Dioscoreaceae), the structure of which contains four free phenolic groups [69]. A molecular docking study on flavones with $\alpha$-glucosidase inhibitory activity has also revealed that replacement of the hydroxyl groups with methoxy groups could lead to loss of activity [70].

Parallel observations were also obtained for the 3-phenylpropyl 3-propionate derivatives (4 and 9). Dihydroconiferyl dihydro- $p$-coumarate (9) showed appreciable activity $\left(\mathrm{IC}_{50} 266.7 \pm 8.6 \mu \mathrm{M}\right)$. However, introducing methoxy groups to C-3 and C-5' of 9 caused a total loss of activity, as seen in dihydrosinapyl dihydroferulate (4). A similar phenomenon, in which the presence of aromatic methoxy groups diminished $\alpha$-glucosidase inhibitory activity, was earlier reported for $p$-coumarate esters of long-chain alcohols [71].

A kinetics study was then performed on compound 3 to analyze the mode of enzyme inhibition using various substrate concentrations $(0.25-2.0 \mathrm{mM})$. From the LineweaverBurk plot in Figure 3A, the drug acarbose showed the intersection of the lines on the $y$-axis, indicating competitive type of inhibition. The $\mathrm{K}_{i}$ value of acarbose $(190.57 \mu \mathrm{M})$ was obtained from the secondary plot by replotting the slopes of the lines against inhibitor concentrations. For compound 3, the increase in concentration ( 4 and $8 \mu \mathrm{M})$ decreased the $\mathrm{V}_{\text {max }}$ from 0.10 to 0.035 but did not affect the $\mathrm{K}_{m}$ value (Figure $3 \mathrm{~B}$ ). The results suggested non-competitive inhibition of the enzyme by 3 . The $\mathrm{K}_{i}$ value of compound $3(4.18 \mu \mathrm{M})$ was obtained from the secondary plot, as shown in Table 5. 

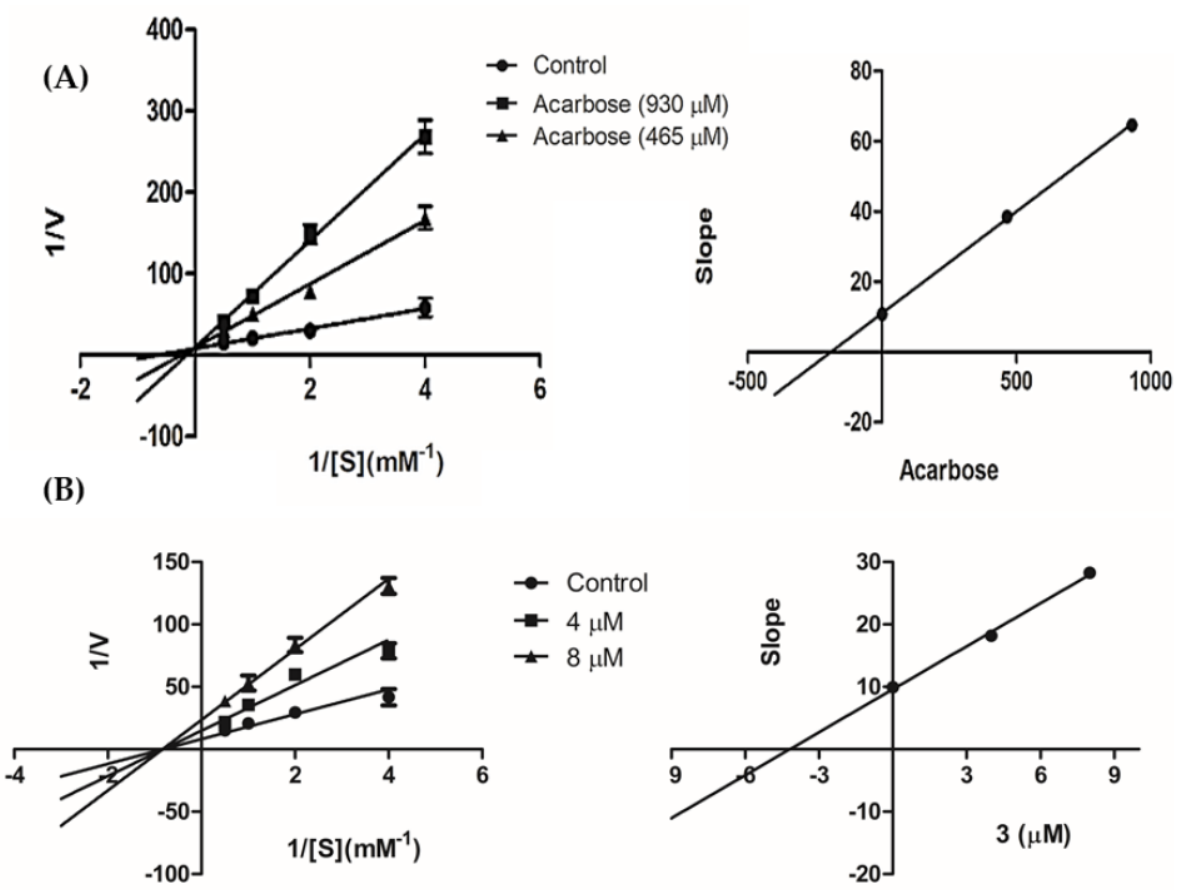

Figure 3. Lineweaver-Burk plots of (A) acarbose and (B) compound 3. The secondary plot of each compound is on the right.

Table 5. Kinetic parameters of $\alpha$-glucosidase inhibition in the presence of 3 .

\begin{tabular}{ccccc}
\hline Inhibitors & Dose $(\mu \mathbf{M})$ & $\mathbf{V}_{\max } \Delta \mathbf{O D} / \mathbf{m i n}$ & $\mathbf{K}_{m}(\mathbf{m M})$ & $\mathbf{K}_{i}(\boldsymbol{\mu M})$ \\
\hline None & - & 0.10 & 1.22 & \\
3 & 8 & 0.035 & 1.20 & 4.18 \\
& 4 & 0.055 & 1.22 & \\
Acarbose & 930 & 0.11 & 6.47 & 190.57 \\
& 465 & 0.10 & 4.17 & \\
\hline
\end{tabular}

$\mathrm{V}_{\max }$, maximum rate of velocity; $\mathrm{K}_{m}$, Michaelis constant; $\mathrm{K}_{i}$, inhibitor constant.

Generally, non-competitive inhibitors have some advantages over competitive inhibitors [72]. Non-competitive inhibitors bind to the allosteric site of the enzyme, and thus do not depend upon the substrate concentration. Moreover, they require lower concentrations than competitive inhibitors to produce the same effect [73]. Compound 3, as a potent non-competitive inhibitor of $\alpha$-glucosidase, provides a lead structure for the further design and development of AGI drugs.

\section{Materials and Methods}

\subsection{Experimental}

Optical rotations were determined with a PerkinElmer Polarimeter 341 (Boston, MA, USA). UV spectra were recorded on a Milton Roy Spectronic 3000 Array spectrophotometer (Rochester, Monroe, NY, USA). IR spectra were obtained with a PerkinElmer FT-IR 1760X spectrophotometer (Boston, MA, USA). Mass spectra were measured using a Bruker MicroTOF mass spectrometer (ESI-MS) (Billerica, MA, USA). NMR spectra were recorded on a Bruker Avance DPX-300FT NMR spectrometer or a Bruker Avance III HD 500 NMR spectrometer (Billerica, MA, USA). Yeast $\alpha$-glucosidase enzyme and $p$-nitrophenol- $\alpha$-Dglucopyranoside were obtained from Sigma Chemical, Inc. (St. Louis, MO, USA), and acarbose was purchased from Fluka Chemical (Buchs, Switzerland). Microtiter plate readings were carried out with a CLARIOstar apparatus (BMGLABTECH, Ortenberg, Germany). 


\subsection{Plant Material}

The plant materials, whole plants of Aerides multiflora, were purchased from Chatuchak market in May 2019. Plant identification was performed by Mr. Yanyong Punpreuk, Department of Agriculture, Bangkok, Thailand. A voucher specimen BS-AM-052562 has been deposited at the Department of Pharmacognosy and Pharmaceutical Botany, Faculty of Pharmaceutical Sciences, Chulalongkorn University.

\subsection{Extraction and Isolation}

The dried powder from the whole plants of Aerides multiflora $(6.1 \mathrm{~kg})$ was macerated with $\mathrm{MeOH}(4 \times 18 \mathrm{~L})$. The $\mathrm{MeOH}$ extract, at a concentration of $100 \mu \mathrm{g} / \mathrm{mL}$, showed $82.4 \pm 9.5 \%$ inhibition of $\alpha$-glucosidase. This $\mathrm{MeOH}$ extract ( $550 \mathrm{~g}$ ) was then suspended in water and partitioned with EtOAc and butanol to give an EtOAc extract (201.1 g), a butanol extract $(80.8 \mathrm{~g})$, and an aqueous extract $(150 \mathrm{~g})$, respectively. The EtOAc extract exhibited $92.9 \pm 3.2$ inhibition at $100 \mu \mathrm{g} / \mathrm{mL}$, whereas the others were devoid of activity $(<50 \%$ inhibition). Therefore, the EtOAc extract was subjected to further investigation.

The EtOAc extract was first fractionated by vacuum liquid chromatography (silica gel, EtOAc- $\mathrm{CH}_{2} \mathrm{Cl}_{2}$, gradient) to give five fractions (A-E). Fraction $\mathrm{B}(11.4 \mathrm{~g}$ ) was further fractionated on a silica gel column (EtOAc-hexane, gradient) to give 3 fractions (BA-BC). Fraction BA (1 g) was separated on Sephadex LH-20 (methanol) to yield fractions BAA, $\mathrm{BAB}$, and BAC. Fraction BAA ( $200 \mathrm{mg})$ was further separated by column chromatography (CC, silica gel, EtOAc- $\mathrm{CH}_{2} \mathrm{Cl}_{2}$, gradient) to give 6-methoxycoelonin (5) (65.4 mg). Fraction $\mathrm{BAB}$ (300 mg) was subjected to $\mathrm{CC}$ (silica gel, EtOAc- $\mathrm{CH}_{2} \mathrm{Cl}_{2}$, gradient) to give fractions BAB1 and BAB2. Fraction BAB1 (160.2 mg) was separated by CC (silica gel, acetonehexane, 3:7) to yield 1 (2.3 mg). Gigantol (6) $(14.5 \mathrm{mg})$ was obtained from fraction BAB2 $(100 \mathrm{mg})$ after purification on Sephadex LH-20 (acetone). Fraction BB (1 g) was separated on Sephadex LH-20 (acetone) to yield BBA and BBB fractions. Fraction BBA (195.8 mg) was subjected to $\mathrm{CC}$ (silica gel, EtOAc- $\mathrm{CH}_{2} \mathrm{Cl}_{2}$, gradient) to yield BBA1 and BBA2 fractions. Fraction BBA1 (132.2 mg) was subjected to CC (silica gel, acetone-hexane, 3:7) to produce imbricatin (7) (39 mg) and agrostonin (8) (7 mg). Fraction C (10.5 g) was fractionated on a silica gel column (EtOAc- $\mathrm{CH}_{2} \mathrm{Cl}_{2}$, gradient) to give 3 fractions (CA-CC). Fraction CB (500 mg) was further separated on Sephadex LH-20 (acetone) to yield CBA and CBB fractions. Fraction CBA $(236.9 \mathrm{mg})$ was further separated by CC (silica gel, EtOAc-hexane, gradient) to give dihydroconiferyl dihydro- $p$-coumarate $(9)(74.1 \mathrm{mg})$ and 5-methoxy-9,10dihydrophenanthrene-2,3,7-triol (10) (9.2 mg). Fraction CC (100 mg) was separated on Sephadex LH-20 (acetone) to yield fractions CCA, CCB, and CCC. Fraction CCB (10 mg) was subjected to $\mathrm{CC}$ (silica gel, EtOAc- $\mathrm{CH}_{2} \mathrm{Cl}_{2}, 0.2$ : 9.8) to yield 2 (3.9 mg). Fraction D (72 g) was chromatographed on a silica gel column (EtOAc- $\mathrm{CH}_{2} \mathrm{Cl}_{2}$, gradient) to give 3 fractions (DA-DC). Fraction DA (1 g) was separated on Sephadex LH-20 (methanol) to yield DAA and DAB fractions. Fraction DAA (300 mg) was re-separated on Sephadex LH20 (acetone) to yield DAA1 and DAA2 fractions. Fraction DAA1 (100 mg) was subjected to CC (silica gel, EtOAc-hexane, 3:7) to give 4 (4.2 mg). Fraction E ( $84.8 \mathrm{~g})$ was subjected to Diaion HP-20 (water-methanol, gradient) to yield five fractions (EA-EE). Fraction EC $(1.7 \mathrm{~g})$ was separated on Sephadex LH-20 (methanol) to yield ECA, ECB and ECC fractions. Fraction ECC (40 mg) was subjected to CC (silica gel, methanol- $\left.\mathrm{CH}_{2} \mathrm{Cl}_{2}, 0.5: 9.5\right)$ to produce 3 (8.8 mg).

Aerimultin A (1): whitish-brown amorphous powder; UV (MeOH) $\lambda_{\max }(\log \varepsilon) 265$ (4.31), 305 (4.2), 315 (4.19); IR: $v_{\max } 3350,2923,2850,1696,1605,1462,1442,1221,1201 \mathrm{~cm}^{-1}$; HR-ESI-MS: [M+Na] ${ }^{+}$at $m / z 565.1841$ (calculated for $\mathrm{C}_{32} \mathrm{H}_{30} \mathrm{O}_{8} \mathrm{Na}, 565.1838$ ); ${ }^{1} \mathrm{H}$ and ${ }^{13} \mathrm{C}$ NMR data, see Table 1.

Aerimultin B (2): brown amorphous solid; $[\alpha] \mathrm{D}^{20}-108$ (c 0.005, MeOH); UV (MeOH) $\lambda_{\max }(\log \varepsilon) 265$ (4.67), 315 (4.09), 370 (3.99); IR: $v_{\max } 3368,2919,2850,1736,1587,1463$, $1259 \mathrm{~cm}^{-1}$; HR-ESI-MS: [M+Na] ${ }^{+}$at $m / z 559.1376$ (calculated for $\mathrm{C}_{32} \mathrm{H}_{24} \mathrm{O}_{8} \mathrm{Na}, 559.1368$ ); ${ }^{1} \mathrm{H}$ and ${ }^{13} \mathrm{C}$ NMR data, see Table 2. 
Aerimultin C (3): brown amorphous solid; $[\alpha]_{\mathrm{D}^{20}}+67.5$ (c 0.008, MeOH); UV (MeOH) $\lambda_{\max }(\log \varepsilon) 265$ (4.1), 315 (3.42), 355 (3.47), 370 (3.48); IR: $v_{\max }$ 3360, 2921, 2851, 1712, 1588, 1461, $1371 \mathrm{~cm}^{-1}$; HR-ESI-MS: [M+Na] ${ }^{+}$at $m / z 533.1218$ (calculated for $\mathrm{C}_{30} \mathrm{H}_{22} \mathrm{O}_{8} \mathrm{Na}$, 533.1212); ${ }^{1} \mathrm{H}$ and ${ }^{13} \mathrm{C}$ NMR data, see Table 2.

Dihydrosinapyl dihydroferulate (4): yellow amorphous solid; UV (MeOH) $\lambda_{\max }(\log \varepsilon)$ 280 (3.76), 315 (3.12); IR: $v_{\max }$ 3432, 2937, 2841, 1723, 1608, 1514, 1455, 1427, 1208, 1111 $\mathrm{cm}^{-1}$; HR-ESI-MS: [M+Na] ${ }^{+}$at $m / z 413.1584$ (calculated for $\mathrm{C}_{21} \mathrm{H}_{26} \mathrm{O}_{7} \mathrm{Na}, 413.1576$ ); ${ }^{1} \mathrm{H}$ and ${ }^{13} \mathrm{C}$ NMR data, see Table 3.

\section{4. $\alpha$-Glucosidase Inhibition Assay}

The assays were performed following previous protocols [74]. The liberation of $p$ nitrophenol from the substrate $p$-nitrophenol- $\alpha$-D-glucopyranoside (PNPG) was observed to determine the inhibition of the $\alpha$-glucosidase enzyme. Each sample was initially dissolved in $50 \%$ DMSO. Then, $0.1 \mathrm{U} / \mathrm{mL}$ of $\alpha$-glucosidase $(40 \mu \mathrm{L})$ in phosphate buffer ( $\mathrm{pH}$ 6.8) was added to each well of a 96-well plate which contained the sample solution $(10 \mu \mathrm{L})$. The plate was pre-incubated at $37^{\circ} \mathrm{C}$ for $10 \mathrm{~min}$. Then, $2 \mathrm{mM} p$-nitrophenol- $\alpha$-Dglucopyranoside $(50 \mu \mathrm{L})$ was added, and the mixture was incubated again at $37^{\circ} \mathrm{C}$ for 20 min. Finally, $1 \mathrm{M} \mathrm{Na}_{2} \mathrm{CO}_{3}$ solution $(100 \mu \mathrm{L})$ was added to terminate the reaction. The absorbance of the mixture was measured at $405 \mathrm{~nm}$ using a microplate reader. Two-fold serial dilution was performed for $\mathrm{IC}_{50}$ determination. The drug acarbose was used as the positive control.

The mode of enzyme inhibition of the test compound was determined using the double reciprocal Lineweaver-Burk plot (1/V vs. 1/[S]). The experiment was performed by varying the PNPG concentrations $(0.25,0.5,1.0$, and $2.0 \mathrm{mM})$ in the absence or presence of compound $3(4 \mu \mathrm{M}$ and $8 \mu \mathrm{M})$ or acarbose $(930 \mu \mathrm{M}$ and $465 \mu \mathrm{M})$. The secondary plot was constructed by replotting the slopes of the lines against inhibitor concentrations, and the $\mathrm{K}_{i}$ was calculated from the line equation of the plot.

\section{Conclusions}

In this communication, ten compounds were isolated from Aerides multiflora, including three new compounds, namely, aerimultins A-C (1-3), the new natural product dihydrosinapyl dihydroferulate (4), and six known compounds (5-10). The structures of the new compounds were established by spectroscopic methods. The findings in this study suggested that biphenanthrenes might be taken as a chemotaxonomic marker for the subfamilies Epidendroideae and Orchidoideae within the family Orchidaceae. For the first time, the dimeric phenanthrenes obtained from this plant family were investigated for an $\alpha$-glucosidase inhibitory activity. Among the isolates, the biphenathrene aerimultin (3) emerged as the most potent inhibitor, showing much higher potency than the drug acarbose. An enzyme kinetic study on this compound revealed a non-competitive type of inhibition and suggested that it could be a candidate structure for $\alpha$-glucosidase inhibitor drug development.

Author Contributions: B.S. conceived, designed, and supervised the research project, as well as prepared and edited the manuscript; M.T.T. performed the experiments and prepared the manuscript; N.C. supervised the $\alpha$-glucosidase inhibition assay; W.M. performed the NMR experiments; Y.P. performed the plant collection; K.L. provided comments and suggestions on the preparation of the manuscript. All authors have read and agreed to the published version of the manuscript.

Funding: This work was supported by the 90th Anniversary of Chulalongkorn University Fund (Ratchadaphiseksomphot Endowment Fund) 2021.

Institutional Review Board Statement: Not applicable.

Informed Consent Statement: Not applicable.

Data Availability Statement: All data presented in this study are available in the article. 
Acknowledgments: M.T.T. is grateful to the Graduate School, Chulalongkorn University for a CUASEAN Ph.D. scholarship.

Conflicts of Interest: The authors declare no conflict of interest.

\section{References}

1. Karunaratne, V.; Thadhani, V.M.; Khan, S.N.; Choudhary, M.I. Potent $\alpha$-glucosidase inhibitors from the lichen Cladonia species from Sri Lanka. J. Natl. Sci. Found Sri. 2014, 42, 95-98. [CrossRef]

2. Wu, J.H.; Micha, R.; Imamura, F.; Pan, A.; Biggs, M.L.; Ajaz, O.; Mozaffarian, D. Omega-3 fatty acids and incident type 2 diabetes: A systematic review and meta-analysis. Br. J. Nutr. 2012, 107, S214-S227. [CrossRef]

3. Chaudhury, A.; Duvoor, C.; Reddy Dendi, V.S.; Kraleti, S.; Chada, A.; Ravilla, R.; Sasapu, A. Clinical review of antidiabetic drugs: Implications for type 2 diabetes mellitus management. Front. Endocrinol. 2017, 8, 1-12. [CrossRef] [PubMed]

4. Nhiem, N.X.; Van Kiem, P.; Van Minh, C.; Ban, N.K.; Cuong, N.X.; Tung, N.H.; Kim, Y.H. $\alpha$-glucosidase inhibition properties of cucurbitane-type triterpene glycosides from the fruits of Momordica charantia. Chem. Pharm. Bull. 2010, 58, 720-724. [CrossRef] [PubMed]

5. Costa, T.M.; Mayer, D.A.; Siebert, D.A.; Micke, G.A.; Alberton, M.D.; Tavares, L.B.B.; De Oliveira, D. Kinetics analysis of the inhibitory effects of alpha-glucosidase and identification of compounds from Ganoderma lipsiense Mycelium. Appl. Biochem. Biotechnol. 2020, 1-14.

6. Hung, H.Y.; Qian, K.; Morris-Natschke, S.L.; Hsu, C.S.; Lee, K.H. Recent discovery of plant-derived anti-diabetic natural products. Nat. Prod. Res. 2012, 29, 580-606. [CrossRef] [PubMed]

7. Nashiru, O.; Koh, S.; Lee, S.Y.; Lee, D.S. Novel $\alpha$-glucosidase from extreme thermophile Thermus caldophilus GK24. J. Biochem. Mol. Biol. 2001, 34, 347-354.

8. Ernawati, T.; Radji, M.; Hanafi, M.; Munim, A.; Yanuar, A. Cinnamic acid derivatives as $\alpha$-glucosidase inhibitor agents. Indones. J. Chem. 2017, 17, 151-160. [CrossRef]

9. Yin, Z.; Zhang, W.; Feng, F.; Zhang, Y.; Kang, W. $\alpha$-Glucosidase inhibitors isolated from medicinal plants. Food Sci. Hum. Well. 2014, 3, 136-174. [CrossRef]

10. Kao, C.C.; Wu, P.C.; Wu, C.H.; Chen, L.K.; Chen, H.H.; Wu, M.S. Risk of liver injury after $\alpha$-glucosidase inhibitor therapy in advanced chronic kidney disease patients. Sci. Rep. 2016, 6, 18996. [CrossRef]

11. Babu, P.S.; Prabuseenivasan, S.; Ignacimuthu, S. Cinnamaldehyde-A potential antidiabetic agent. Phytomedicine 2007, 14, 15-22. [CrossRef]

12. Liu, M.; Qi, C.; Sun, W.; Shen, L.; Wang, J.; Liu, J.; Zhang, Y. $\alpha$-Glucosidase inhibitors from the coral-associated fungus Aspergillus terreus. Front. Chem. 2018, 6, 422. [CrossRef]

13. Limpanit, R.; Chuanasa, T.; Likhitwitayawuid, K.; Jongbunprasert, V.; Sritularak, B. $\alpha$-Glucosidase inhibitors from Dendrobium tortile. Rec. Nat. Prod. 2016, 10, 609-616.

14. Sun, J.; Zhang, Y.; Chen, L.; Zhan, R.; Chen, Y. A new phenanthrene and a new 9,10-dihydrophenanthrene from Bulbophyllum retusiusculum. Nat. Prod. Res. 2018, 32, 2447-2451. [CrossRef] [PubMed]

15. Auberon, F.; Olatunji, O.J.; Waffo-Teguo, P.; Adekoya, A.E.; Bonte, F.; Merillon, J.M.; Lobstein, A. New glucosyloxybenzyl 2R-benzylmalate derivatives from the underground parts of Arundina graminifolia (Orchidaceae). Fitoterapia 2019, 135, 33-43. [CrossRef] [PubMed]

16. Kocyan, A.; de Vogel, E.F.; Conti, E.; Gravendeel, B. Molecular phylogeny of Aerides (Orchidaceae) based on one nuclear and two plastid markers: A step forward in understanding the evolution of the Aeridinae. Mol. Phylogenet. Evol. 2008, 48, 422-443. [CrossRef] [PubMed]

17. Pant, B. Medicinal orchids and their uses: Tissue culture a potential alternative for conservation. Afr. J. Plant Sci. 2013, 7, 448-467. [CrossRef]

18. Akter, M.; Huda, M.K.; Hoque, M.M. Investigation of secondary metabolites of nine medicinally important orchids of Bangladesh. J. Pharmacogn. Phytochem. 2018, 7, 602-606.

19. Cakova, V.; Urbain, A.; Antheaume, C.; Rimlinger, N.; Wehrung, P.; Bonté, F.; Lobstein, A. Identification of phenanthrene derivatives in Aerides rosea (Orchidaceae) using the combined systems HPLC-ESI-HRMS/MS and HPLC-DAD-MS-SPE-UVNMR. Phytochem. Anal. 2015, 26, 34-39. [CrossRef]

20. Anuradha, V.; Rao, N.P. Aeridin: A phenanthropyran from Aerides crispum. Phytochemistry 1998, 48, 185-186. [CrossRef]

21. Bhowmik, T.K.; Rahman, M.M. In vitro study of medicinally important orchid Aerides multiflora Roxb. from nodal and leaf explants. J. Pharmacog. Phytochem. 2020, 9, 179-184.

22. Choon, K.K. Management of the Pha Taem Protected Forest Complex to Promote Cooperation for Transboundary Biodiversity Conservation between Thailand, Cambodia and Laos Phase I; Kasetsart University: Bangkok, Thailand, 2004.

23. Schuiteman, A.; Bonnet, P.; Svengsuksa, B.; Barthélémy, D. An annotated checklist of the Orchidaceae of Laos. Nord. J. Bot. 2008, 26, 257-316. [CrossRef]

24. Subedi, A.; Kunwar, B.; Choi, Y.; Dai, Y.; Van Andel, T.; Chaudhary, R.P.; De Boer, H.J.; Gravendeel, B. Collection and trade of wild-harvested orchids in Nepal. J. Ethnobiol. Ethnomed. 2013, 9, 1-10. [CrossRef]

25. Gogoi, K.; Das, R.; Yonzone, R. Present ecological status, diversity, distribution and cultural significance of the genus Aerides Loureiro (Orchidaceae) in Tinsukia District (Assam) of North East India. J. Environ. Ecol. 2012, 30, 649-651. 
26. Rao, A.N. Medicinal orchid wealth of Arunachal Pradesh. Indian Med. Plants 2004, 1, 1-7.

27. Ghanaksh, A.; Kaushik, P. Antibacterial effect of Aerides multiflora: A study in vitro. J. Orchid Soc. India 1999, 1, 65-68.

28. Inthongkaew, P.; Chatsumpun, N.; Supasuteekul, C.; Kitisripanya, T.; Putalun, W.; Likhitwitayawuid, K.; Sritularak, B. $\alpha-$ Glucosidase and pancreatic lipase inhibitory activities and glucose uptake stimulatory effect of phenolic compounds from Dendrobium formosum. Rev. Bras. Farmacogn. 2017, 27, 480-487. [CrossRef]

29. Sarakulwattana, C.; Mekboonsonglarp, W.; Likhitwitayawuid, K.; Rojsitthisak, P.; Sritularak, B. New bisbibenzyl and phenanthrene derivatives from Dendrobium scabrilingue and their $\alpha$-glucosidase inhibitory activity. Nat. Prod. Res. 2020, 34, 1694-1710. [CrossRef] [PubMed]

30. Thant, M.T.; Chatsumpun, N.; Mekboonsonglarp, W.; Sritularak, B.; Likhitwitayawuid, K. New fluorene derivatives from Dendrobium gibsonii and their $\alpha$-glucosidase inhibitory activity. Molecules 2020, 25, 4931. [CrossRef]

31. Leong, Y.W.; Kang, C.C.; Harrison, L.J.; Powell, A.D. Phenanthrenes, dihydrophenanthrenes and bibenzyls from the orchid Bulbophyllum vaginatum. Phytochemistry 1997, 44, 157-165. [CrossRef]

32. Chen, Y.; Xu, J.; Yu, H.; Qing, C.; Zhang, Y.; Wang, L.; Liu, Y.; Wang, J. Cytotoxic phenolics from Bulbophyllum odoratissimum. Food Chem. 2008, 107, 169-173. [CrossRef]

33. Simmler, C.; Antheaume, C.; Lobstein, A. Antioxidant biomarkers from Vanda coerulea stems reduce irradiated HaCaT PGE-2 production as a result of COX-2 inhibition. PLoS ONE 2010, 5, 1-9. [CrossRef] [PubMed]

34. Majumder, P.L.; Banerjee, S.; Lahiri, S.; Mukhoti, N.; Sen, S. Dimeric phenanthrenes from two Agrostophyllum species. Phytochemistry 1998, 47, 855-860. [CrossRef]

35. Zhang, X.; Gao, H.; Wang, N.; Yao, X. Phenolic components from Dendrobium nobile. Zhong Cao Yao 2006, 37, $652-655$.

36. Leong, Y.W.; Kang, C.C.; Harrison, L.J.; Powell, A.D. Phenanthrene and other aromatic constituents of Bulbophyllum vaginatum. Phytochemistry 1998, 50, 1237-1241. [CrossRef]

37. Estrada, S.; Toscano, R.A.; Mata, R. New Phenanthrene derivatives from Maxillaria densa. J. Nat. Prod. 1999, 62, 1175-1178. [CrossRef]

38. Majumder, P.L.; Sabzabadi, E. Agrostophyllin, a naturally occurring phenanthropyran derivative from Agrostophyllum khasiyanum. Phytochemistry 1988, 27, 1899-1901. [CrossRef]

39. Liu, L.; Yin, Q.M.; Zhang, X.W.; Wang, W.; Dong, X.Y.; Yan, X.; Hu, R. Bioactivity-guided isolation of biphenanthrenes from Liparis nervosa. Fitoterapia 2016, 115, 15-18. [CrossRef]

40. Beck, J.J.; Kim, J.H.; Campbell, B.C.; Chou, S.C. Fungicidal activities of dihydroferulic acid alkyl ester analogues. J. Nat. Prod. 2007, 70, 779-782. [CrossRef]

41. Zhuo, J.X.; Wang, Y.H.; Su, X.L.; Mei, R.Q.; Yang, J.; Kong, Y.; Long, C.L. Neolignans from Selaginella moellendorffii. Nat. Prod. Bioprospect. 2016, 6, 161-166. [CrossRef]

42. Sibout, R.; Le Bris, P.; Legee, F.; Cezard, L.; Renault, H.; Lapierre, C. Structural redesigning Arabidopsis lignins into alkali-soluble lignins through the expression of $p$-coumaroyl-CoA: Monolignol transferase PMT. Plant Physiol. 2016, 170, 1358-1366. [CrossRef]

43. Zhang, G.Q.; Liu, K.W.; Chen, L.J.; Xiao, X.J.; Zhai, J.W.; Li, L.Q.; Liu, Z.J. A new molecular phylogeny and a new genus, Pendulorchis, of the Aerides-Vanda alliance (Orchidaceae: Epidendroideae). PLoS ONE 2013, 8, e60097. [CrossRef] [PubMed]

44. Li, Y.X.; Li, Z.H.; Schuiteman, A.; Chase, M.W.; Li, J.W.; Huang, W.C.; Hidayat, A.; Wu, S.S.; Jin, X.H. Phylogenomics of Orchidaceae based on plastid and mitochondrial genomes. Mol. Phylogenet. Evol. 2019, 139, 106540. [CrossRef] [PubMed]

45. Lucca, D.L.; Sa, G.P.; Polastri, L.R.; Ghiraldi, D.M.; Ferreira, N.P.; Chiavelli, L.U.; Pomini, A.M. Biphenanthrene from Stanhopea lietzei (Orchidaceae) and its chemophenetic significance within neotropical species of the Cymbidieae tribe. Biochem. Syst. Ecol. 2020, 89, 104014. [CrossRef]

46. Qian, C.D.; Jiang, F.S.; Yu, H.S.; Shen, Y.; Fu, Y.H.; Cheng, D.Q.; Ding, Z.S. Antibacterial Biphenanthrenes from the fibrous roots of Bletilla striata. J. Nat. Prod. 2015, 78, 939-943. [CrossRef]

47. Guo, X.Y.; Wang, J.; Wang, N.L.; Kitanaka, S.; Liu, H.W.; Yao, X.S. New stilbenoids from Pholidota yunnanensis and their inhibitory effects on nitric oxide production. Chem. Pharm. Bull. 2006, 54, 21-25. [CrossRef]

48. Xu, J.; Yu, H.; Qing, C.; Zhang, Y.; Liu, Y.; Chen, Y. Two new biphenanthrenes with cytotoxic activity from Bulbophyllum odoratissimum. Fitoterapia 2009, 80, 381-384. [CrossRef] [PubMed]

49. Zhang, G.N.; Zhong, L.Y.; Bligh, S.A.; Guo, Y.L.; Zhang, C.F.; Zhang, M.; Xu, L.S. Bi-bicyclic and bi-tricyclic compounds from Dendrobium thyrsiflorum. Phytochemistry 2005, 66, 1113-1120. [CrossRef]

50. Yang, M.; Cai, L.; Tai, Z.; Zeng, X.; Ding, Z. Four new phenanthrenes from Monomeria barbata Lindl. Fitoterapia 2010, 81, 992-997. [CrossRef]

51. Liu, L.; Li, J.; Zeng, K.W.; Jiang, Y.; Tu, P.F. Five new biphenanthrenes from Cremastra appendiculata. Molecules 2016, 21, 1089. [CrossRef]

52. Auberon, F.; Olatunji, O.J.; Herbette, G.; Raminoson, D.; Antheaume, C.; Soengas, B.; Lobstein, A. Chemical constituents from the aerial parts of Cyrtopodium paniculatum. Molecules 2016, 21, 1418. [CrossRef]

53. Wang, C.; Shao, S.Y.; Han, S.W.; Li, S. Atropisomeric bi (9, 10-dihydro) phenanthrene and phenanthrene/bibenzyl dimers with cytotoxic activity from the pseudobulbs of Pleione bulbocodioides. Fitoterapia 2019, 138, 104313. [CrossRef]

54. Auberon, F.; Olatunji, O.J.; Krisa, S.; Antheaume, C.; Herbette, G.; Bonté, F.; Lobstein, A. Two new stilbenoids from the aerial parts of Arundina graminifolia (Orchidaceae). Molecules 2016, 21, 1430. [CrossRef] 
55. Shi, X.; Li, Y.; Liu, Y.; Jiang, J.; Wang, L.; Zhang, Y.; Chen, Y. A new 9, 10-dihydrophenanthropyran dimer and a new natural 9 , 10-dihydrophenanthropyran from Otochilus porrectus. Biochem. Syst. Ecol. 2010, 38, 842-845. [CrossRef]

56. Majumder, P.L.; Banerjee, S. Structure of flavanthrin, the first dimeric 9, 10-dihydrophenanthrene derivative from the orchid Eria flava. Tetrahedron 1988, 44, 7303-7308. [CrossRef]

57. Tuchinda, P.; Udchachon, J.; Khumtaveeporn, K.; Taylor, W.C.; Engelhardt, L.M.; White, A.H. Phenanthrenes of Eulophia nuda. Phytochemistry 1988, 27, 3267-3271. [CrossRef]

58. Majumder, P.L.; Pal, A.; Joardar, M. Cirrhopetalanthrin, a dimeric phenanthrene derivative from the orchid Cirrhopetalum maculosum. Phytochemistry 1990, 29, 271-274. [CrossRef]

59. Lee, C.L.; Chang, F.R.; Yen, M.H.; Yu, D.; Liu, Y.N.; Bastow, K.F.; Morris-Natschke, S.L.; Wu, Y.C.; Lee, K.S. Cytotoxic phenanthrenequinones and 9,10-dihydrophenanthrenes from Calanthe arisanensis. J. Nat. Prod. 2009, 72, 210-213. [CrossRef]

60. Majumder, P.L.; Lahiri, S. Volucrin, a new dimeric phenanthrene derivative from the orchid Lusia volucris. Tetrahedron 1990, 46, 3621-3626. [CrossRef]

61. Gutierrez, R.M.P.; Gonzalez, A.M.N.; Baez, E.G.; Diaz, S.L. Studies on the constituents of bulbs of the orchid Prosthechea michuacana and antioxidant activity. Chem. Nat. Compd. 2010, 46, 554-561. [CrossRef]

62. Li, C.Y.; Liu, J.; Su, X.H.; Yuan, Z.P.; Zhong, Y.J.; Li, Y.F.; Liang, B. New dimeric phenanthrene and flavone from Spiranthes sinensis. J. Asian Nat. Prod. Res. 2013, 15, 417-421. [CrossRef]

63. Matsuda, H.; Morikawa, T.; Xie, H.; Yoshikawa, M. Antiallergic phenanthrenes and stilbenes from the tubers of Gymnadenia conopsea. Planta Med. 2004, 70, 847-855. [CrossRef]

64. Niu, Z.; Xue, Q.; Zhu, S.; Sun, J.; Liu, W.; Ding, X. The complete plastome sequences of four orchid species: Insights into the evolution of the Orchidaceae and the utility of plastomic mutational hotspots. Front. Plant Sci. 2017, 8, 715. [CrossRef]

65. Ernawati, T. In silico evaluation of molecular interactions between known $\alpha$-glucosidase inhibitors and homologous $\alpha$-glucosidase enzymes from Saccharomyces cerevisiae, Rattus norvegicus and GANC-human. Thai J. Pharm. Sci. 2018, 42.

66. Dhanawansa, R.; Faridmoayer, A.; van der Merwe, G.; Li, Y.X.; Scaman, C.H. Overexpression, purification, and partial characterization of Saccharomyces cerevisiae processing alpha glucosidase I. J. Glycobiol. 2002, 12, 229-234. [CrossRef] [PubMed]

67. Liu, J.L.; Kong, Y.C.; Miao, J.Y.; Mei, X.Y.; Wu, S.Y.; Yan, Y.C.; Cao, X.Y. Spectroscopy and molecular docking analysis reveal structural specificity of flavonoids in the inhibition of $\alpha$-glucosidase activity. Int. J. Biol. Macromol. 2020, 152, 981-989. [CrossRef]

68. Rosas-Ramírez, D.; Pereda-Miranda, R.; Escandón-Rivera, S.; Arreguín-Espinosa, R. Identification of $\alpha$-glucosidase inhibitors from Ipomoea alba by affinity-directed fractionation-mass spectrometry. Rev. Bras. Farmacogn. 2020, 30, 336-345. [CrossRef]

69. Zhao, Y.; Kongstad, K.T.; Liu, Y.; He, C.; Staerk, D. Unraveling the complexity of complex mixtures by combining high-resolution pharmacological, analytical and spectroscopic techniques: Antidiabetic constituents in Chinese medicinal plants. Faraday Discuss. 2019, 218, 202-218. [CrossRef] [PubMed]

70. Proença, C.; Freitas, M.; Ribeiro, D.; Oliveira, E.F.; Sousa, J.L.; Tomé, S.M.; Fernandes, E. $\alpha$-glucosidase inhibition by flavonoids: An in vitro and in silico structure-activity relationship study. J. Enzyme Inhib. Med. Chem. 2017, 32, 1216-1228. [CrossRef] [PubMed]

71. San, H.T.; Boonsnongcheep, P.; Putalun, W.; Mekboonsonglarp, W.; Sritularak, B.; Likhitwitayawuid, K. $\alpha$-glucosidase inhibitory and glucose uptake stimulatory effects of phenolic compounds from Dendrobium christyanum. Nat. Prod. Commun. 2020, 15. [CrossRef]

72. Chougale, A.D.; Ghadyale, V.A.; Panaskar, S.N.; Arvindekar, A.U. Alpha glucosidase inhibition by stem extract of Tinospora cordifolia. J. Enzyme Inhib. Med. Chem. 2009, 24, 998-1001. [CrossRef] [PubMed]

73. Ghadyale, V.; Takalikar, S.; Haldavnekar, V.; Arvindekar, A. Effective control of postprandial glucose level through inhibition of intestinal alpha glucosidase by Cymbopogon martinii (Roxb.). Evid. Based Complement. Altern. Med. 2012, 1-6. [CrossRef]

74. Chatsumpun, N.; Sritularak, B.; Likhitwitayawuid, K. New biflavonoids with $\alpha$-glucosidase and pancreatic lipase inhibitory activities from Boesenbergia rotunda. Molecules 2017, 22, 1862. [CrossRef] [PubMed] 